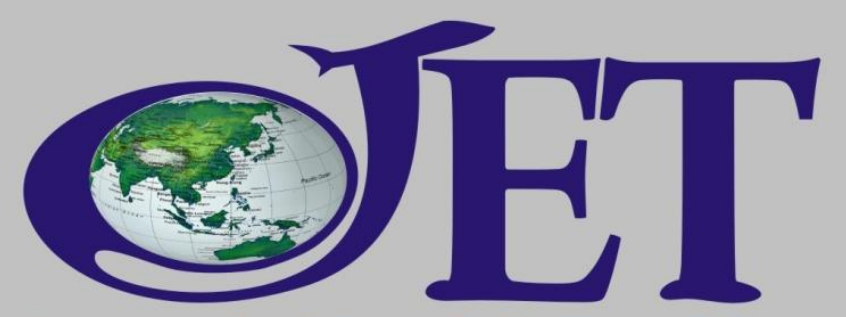

Journal of English Teaching a

triannual

publication

on the study of

English Language Teaching

Volume 1, Number 1, February 2011

\title{
Students’ View on Grammar Teaching
}

\author{
Hendrikus Male \\ Christian University of Indonesia \\ Jakarta, Indonesia \\ e-mail: hendrymalle@yahoo.com
}

\begin{abstract}
The focal point of this paper is on the view of the fifth semester students of FKIP UKI on the teaching of English grammar which was gauged through a study conducted in November 2010. The findings of the study, obtained via quantitative and qualitative approaches, revealed that a majority of the respondents basically viewed grammar is important in their study of English. They also viewed knowledge of grammar plays an important role in writing, but has no significant role in speaking. In addition, the respondents seemed to prefer explicit than implicit teaching in their trial to master English grammar. The paper concludes by suggesting the need to explore new approaches to the teaching of grammar to enhance students' autonomy in learning grammar.
\end{abstract}

Keywords: English grammar, EFL, students' view, explicit teaching, implicit teaching 


\section{Introduction}

During the long history of foreign language teaching and learning, the role of grammar teaching has possibly been one of the most hotly debated aspects. At one extreme, the proponents of grammar teaching contend that grammar should be made a primary focus of language instruction. They argue that the fundamental reason for learning a language is to use it as a mean of communication, and grammar is the 'stuff'-which operates not only at the simplest level of a sentence but also beyond it—with which we communicate. At the other extreme, the anti-grammar asserts that grammar should be eliminated entirely from language teaching because language should be acquired through natural exposure, not learned through formal instruction. Influenced by this viewpoint, some teachers steadily insist teaching formal grammar is useless and even harmful, and the anti-grammar tide reached its peak in November 1985, when the National Council of Teachers of English (NCTE) passed a resolution against the use of isolated grammar and usage exercises not supported by theory and research (Wang, 2010).

Like it or not, the endless debate has caused many teachers of English as a foreign language (henceforward EFL) worried about the status of grammar within the process of teaching and learning. They feel uncertain whether they should teach it or not, and how this is best to be carried out. Much research has actually been conducted in order to help the teachers solve the problems. Some of the research has also addressed what researchers and educators believe are the best methods to accommodate students' needs in relation to grammar. However, students' views regarding grammar teaching in EFL learning have rarely been touched in literature, whereas the students' opinions are important as they can throw light on the teaching process. Tomlison (2005, pp. 140-142) exposes that to succeed an EFL teaching, the students' expectations, needs and wants, attitudes and learning styles should be considered.

This paper discusses the findings of a study recently undertaken to investigate the students' perceptions on grammar instruction at the English Teaching Study Program of the Faculty of Education and Teachers Training of the Christian University of Indonesia (henceforward FKIP-UKI) Jakarta.

\section{Literature Review}

The role of grammar teaching has been the subject of significant controversy in the field of language teaching and learning (Ellis 2006). Until 1940s, under the influence of the Grammar-Translation Method (GTM), the teaching of grammar had been central to and often been synonymous with foreign language teaching for more than 25 centuries (Rutherford, 1987). When two other dominant approaches called Audio-Lingual and Situational Language Teaching successively replaced the GTM, grammar instruction still played an important role. However, with the advent of the communicative approach in the 
late 1970s, the role of grammar instruction in second and foreign language learning was downplayed. Language acquisition researchers like Krashen (1985), Terrell (1977), and Hammond (1988) argued against focus on form, and suggested that error correction may actually do more harm than good. It was even suggested that teaching grammar was not only unhelpful but might actually be detrimental (Nassaji \& Fotos, 2004). Since then, the necessity of grammar instruction has become the center of an ongoing debate.

The continuing debate on the status of grammar instruction over the past few decades has concentrated on determining whether grammar should be taught at all. According to Nassaji and Fotos (2004), the arguments against grammar teaching could be represented by Krashen's (1981) distinction between conscious learning and unconscious acquisition of language. It was claimed that language should be acquired through natural exposure, not learned through formal instruction. It was therefore believed that formal grammar lessons would increase only declarative knowledge of grammar structures, not the ability to use forms correctly. This position was supported by results of some researches on grammar teaching which led to the conclusion that it was simply a waste of time in the sense that most children could not apply any of the categories even after many years of teaching (Hudson 1998).

The proponents of grammar teaching argue that some focus on "form" may well be necessary for many students to achieve accuracy as well as fluency in their acquisition of a second or foreign language (Long, 1983; Rutherford \& Smith, 1988). The fact that the main objective of learning a language is to use it as a means of communication makes grammar essential. Zang (2009) argues "Grammatical competence is one of communicative competence. Communicative competence involves knowing how to use the grammar and vocabulary of the language to achieve communicative goals, and knowing how to do this in a socially appropriate way. Communicative goals are the goals of students' studying English language. So grammar teaching is necessary to achieve the goals".

This position was strongly supported by the results of a large number of laboratory and classroom-based studies which indicated the positive effects of grammar instruction. For example, studies of the effects of instruction on the development of specific target language forms (e.g., Cadierno, 1995; Lightbown, 1992) as well as corrective feedback on learner errors (Carroll \& Swain, 1993; Nassaji \& Swain, 2000) indicate that grammatical instruction has a significant effect on the attainment of accuracy. In addition, a recent metaanalysis of 49 studies on the effectiveness of L2 instruction (Norris \& Ortega, 2000) concludes that explicit instruction (presenting the structure, describing and exemplifying it, and giving rules for its use) results in substantial gains in the learning of target structures in comparison to implicit instruction (usually 
consisting of communicative exposure to the target form) alone, and that these gains are durable over time.

Despite the controversy, several studies carried out in EFL teaching do seem to indicate that students find explicit grammar instruction helpful in language learning. The fact that most EFL students have limited communicative input and the real-world needs for communicative functions in the target language makes grammar-based syllabi become the common the norm. Wang's (2010) study revealed that "middle school students from China believe that grammar is very important and necessary because the students had few opportunities and little time to get enough input inside and outside the class." Based on the result of his research in Japan, Takahashi (2005) states: “... without a sound knowledge of the grammatical basis of a second or a foreign language, the learner is in possession of nothing more than a selection of everyday phrases which are adequate for basic greetings and making orders at a restaurant, but which will be deficient when the learner is required to perform any kind of sophisticated linguistic task” (p. 231). He then concludes: “... it is of vital importance for EFL students to learn its grammar of the target language, and that there is a positive correlation between grammar learning and language competence" (p. 232). Ozkana \& Kesen's (2009) research in Turkey indicated that grammar teaching does really make a significant difference in EFL. It is also in line with Rahimpour \& Salimi's (2010) study results in Iran which indicated that implicit instruction has no role in triggering students' English development in EFL context.

While there is abundant literature focuses on grammar teaching and error correction in foreign language classrooms (Ellis, 2002; Schulz, 2001) and on teachers' views (Farrell \& Particia, 2005), little research has been carried out regarding students' perspectives on their use in the EFL classroom. Studies that do look at students' beliefs typically focus on language learning in general and not on the role of grammar instruction in particular, although it has been the topic of many debates in the field. Therefore, in order to determine whether grammar should be taught explicitly or implicitly and what activities and techniques are best to teach and learn it, students' views need to be considered. Teachers' awareness of students' belief in this context will surely be beneficial to the teaching and learning process. Such awareness will at least enable teachers to realize the mismatch in perception between students and teachers on the use of grammar which often exists in classrooms and may result in negative effects (Horowitz, 1990).

\section{Methodology}

This study employed the explanatory mixed method design, which, according to Creswell et al. (2003) enables us to gather qualitative input to 
explain and extend quantitative results, in order to gain a comprehensive insight of the research. A '14 item questionnaire', which was adapted from Palacios (2006), was administered to obtain quantitative input. The questionnaire was constructed to measure the respondents' views of the teaching of English grammar. Before it is utilized to collect the data, the questionnaire was tested in a preliminary pilot study conducted with eight students. The pilot study served to see whether the wording of the questions was clear and the completion of the tasks was feasible. Minor changes were introduced in the original plan as a result of this process.

The data were collected in the odd semester of Academic Year 2010/2011 (November 2010). The respondents were all the fifth-semester students of the English Teaching Study Program of FKIP-UKI. They were purposively selected on the assumption that they had passed all language grammar classes and almost finished all language skill classes in which they were supposed to apply grammatical knowledge they had studied. Since they had experienced the use of the pattern of the English structure and had got the knowledge on English grammar rules. The students were supposed to properly respond to the questionnaire. There were actually 54 students of semester six in the study program when the data were taken. However, 8 of them were involved in the pilot study carried out to determine the reliability of the instrument. Thus, the other 46 students were asked to indicate their agreement or disagreement to each statement on a 5-point Likert scale that ranged from strongly disagree, score 1 , to strongly agree, score 5 .

A focused semi structured open-ended interviews was also employed to enrich and support the quantitative findings. The themes that emerged during the interview sessions were coded in accordance to the quantitative dimensions obtained from the questionnaire. 15-20 minute interview sessions were conducted with 5 volunteers, who were respondents to the questionnaire administered. The rationale for using focused semi structured open-ended interviews was to understand the respondents' point of view rather than make generalizations.

\section{Results and Discussion}

The following sections discuss the students' view on the teaching of English grammar in the English Teaching Study Program of FKIP-UKI in the academic year of 2010/2011.

The fourteen items included in the questionnaire can be divided into two sections. The first four statements concentrate on students' attitudes towards the importance and value of grammar in learning English and for an accurate 
written and spoken English use. The other ten affirmations focus on students' positions on the pedagogy of grammar. They include instructional approaches (explicit vs. implicit) and activities and techniques for its teaching and presentation: teacher's explanations, contrastive analysis between Indonesian and English, use of rules, contextualized practice, discovery learning tasks, practical exercises, study of terminology, and sentence parsing.

\section{Views on the Importance of Grammar Teaching}

The distribution of the respondents' view (as shown in table 1 below) revealed that the students' view on the importance of grammar in English learning and use was very high. The findings denoted that $70 \%$ of the respondents strongly agreed, $25 \%$ agreed; and only the rest $8 \%$ disagreed. The average obtained for this particular point is 4.59 on a scale from 1 to 5 . The qualitative data related to this dimension seem to echo similar views, as indicated in the excerpt $\mathrm{s}$ below.

Yes, Grammar is very important. It is the rules for organizing your words to form meaningful sentences. If you don't know the grammar how can you create good sentences? (Interviewee B)

Grammar is surely very important. It helps people comprehend or get meaning in communication. (Interviewee $\mathrm{C}$ )

Grammar is the law of language. It is the rules for building correct sentences. So, it is very important in one's trial to master English. (Interviewee D)

Table 1: Students' View on the Importance of Grammar in English Learning and Use

\begin{tabular}{|c|c|c|c|c|c|c|c|}
\hline \multirow{3}{*}{ No } & \multirow{3}{*}{ STATEMENTS } & \multicolumn{5}{|c|}{ RESPONSES } & \multirow{3}{*}{$\mathrm{X}$} \\
\hline & & SA & A & $\mathrm{N}$ & $\mathrm{D}$ & SD & \\
\hline & & $\mathrm{f}(\%)$ & $\mathrm{f}(\%)$ & f (\%) & $\mathrm{f}(\%)$ & $\mathrm{f}(\%)$ & \\
\hline 1 & $\begin{array}{l}\text { Grammar plays an } \\
\text { important role in the } \\
\text { study of English. }\end{array}$ & $38(70)$ & $13(25)$ & $0(0)$ & $3(5)$ & $0(0)$ & 4.59 \\
\hline 2 & $\begin{array}{l}\text { The knowledge of } \\
\text { English grammar is } \\
\text { indispensable for using } \\
\text { the language to } \\
\text { communicate. }\end{array}$ & $4(7)$ & $12(23)$ & $4(7)$ & $18(33)$ & $16(30)$ & 2.44 \\
\hline
\end{tabular}




\begin{tabular}{|l|l|c|c|c|c|c|c|}
\hline 3 & $\begin{array}{l}\text { It is possible to speak } \\
\text { English well without any } \\
\text { grammatical knowledge }\end{array}$ & $30(56)$ & $10(18)$ & $8(16)$ & $3(5)$ & $3(5)$ & 4.12 \\
\hline 4 & $\begin{array}{l}\text { It is possible to write } \\
\text { English well without any } \\
\text { grammatical knowledge }\end{array}$ & 0 & $7(13)$ & $14(26)$ & $14(26)$ & $19(35)$ & 2.16 \\
\hline
\end{tabular}

The findings related to the students' view on the importance of grammar in communication were quite striking. The average obtained for this particular point is only 2.44 on a scale from 1 to 5 . According to $63 \%$ of the respondents, grammar does not play an important role in the use of English to communicate. Only $7 \%$ of them strongly agreed and $23 \%$ agreed that the knowledge of English grammar is indispensable for using the language to communicate (see item 2 of table 1 above). This is in line with the average of 4.12 obtained from their affirmation to the possibility of speaking well in English without grammatical knowledge. Seeing from the percentage of the responses given to this point, almost three-fourth (i.e. 74\%) of the respondents strongly agreed and agreed, but only $10 \%$ strongly disagreed and disagreed (see item 3 of table 1). The data obtained through interviews strengthen their view that grammar does not play an important role in speaking, as indicated in the following excerpts.

Using grammar rules in a conversation? Wow, it will make you unable to speak fluently. What is more, it seems that even native speakers' sometimes break grammar rules in speaking. (Interviewee A)

Well, I got good scores in grammar classes. That indicates my grammar is good. But I don't think I my expression should apply the rules of grammar I have studied. I often realized that some of my utterances were not grammatical. But, in my opinion, as far as my message is understood, it's $O K$. (Interviewee E)

However, the students' view on the importance of grammar for communication is not in line with their idea of the importance of grammar in writing. The findings denoted that $61 \%$ of the respondents strongly disagreed and disagreed that it is possible to write well in English without mastering the grammar. Only $13 \%$ of them viewed it is possible to write well without mastering the grammar. The data obtained through interviews, as indicated in the following excerpts, support their view that grammar does play an important role in writing.

I think it's impossible to write well without applying grammatical rules. Different from the errors you made in speaking, the errors in writing, 
even the trivial errors, could be easily identified. Thus, grammar is very important in writing. (Interviewee A)

How can you combine words into sentences and arrange sentences to make a paragraph, if you don't know grammar? When you arrange words in correct order, you will get meaningful sentence. When you change the order, the meaning will change. Grammar operates in all aspects of your writings. (Interviewee B)

If your grammar is not correct, your sentence is not accurate, and people cannot understand what you mean. By knowing grammatical rules, such as the agreement between the subject and the verb of a sentence, you can easily check any mistake you make in your writing. So, grammar is a must in writing. (Interviewee E)

These contrastive views on the importance of grammar in speaking and writing indicated the respondents' tendency to correlate grammar with written language only. They probably did not see the correlation of grammar with spoken communication. It is also possible that when referring to writing these students meant being able to communicate accurately and their reference to speaking was the ability to express their ideas effectively.

\section{Views on the techniques and activities for the teaching and learning of grammar}

The distribution of the respondents' views concerning with different techniques and activities for the teaching and learning of grammar revealed that, practical exercises, contrastive analysis, and studying the rules of grammar are three most useful learning activities for their understanding of the language system. Successively, the average obtained for these three were 4.4, 4.27, and 4.14 (see table 2). These three are followed by contextualized grammar practice, syntactic parsing, and lecturer's explanations (rated successively with the values of 4.11, 4.09 and 4.07), which indicated that the respondents regarded the activity of analyzing phrase or sentence as important and the presentation of grammar made by their lecturers.

The respondents' fondness of these six activities and techniques confirm the distribution of the respondents' views concerning with the statement that grammar must be taught explicitly rather than implicitly. It was found that $41 \%$ of the respondents strongly agreed; $36 \%$ agreed; $11 \%$ neutral; and only $12 \%$ disagreed and strongly disagreed. The average obtained for this particular point was 4 (on a scale where, as previously stated, the top value is 5). This finding is also supported by the quite high average (3.81) obtained for the importance of 
studying terminology in the learning of English grammar. Contrastive analysis, studying the rules of grammar, and syntactic parsing are activities which require students' knowledge of grammatical terminologies.

These findings that the respondents did prefer explicit teaching rather than implicit teaching in studying grammar were strengthened by the data obtained through interviews, as indicated in the following excerpts.

Table 2: Students' Views on the techniques and activities for the teaching and learning of grammar

\begin{tabular}{|c|c|c|c|c|c|c|c|}
\hline \multirow{3}{*}{ No } & \multirow{3}{*}{ STATEMENTS } & \multicolumn{5}{|c|}{ RESPONSES } & \multirow{3}{*}{$\mathrm{X}$} \\
\hline & & SA & $\mathrm{A}$ & $\mathrm{N}$ & $\mathrm{D}$ & SD & \\
\hline & & $\mathrm{f}(\%)$ & $\mathrm{f}(\%)$ & $\mathrm{f}(\%)$ & $\mathrm{f}(\%)$ & $\mathrm{f}(\%)$ & \\
\hline 1 & $\begin{array}{l}\text { Lecture's explanations } \\
\text { are in general useful for } \\
\text { the study of Grammar }\end{array}$ & $14(26)$ & $34(62)$ & $3(6)$ & $3(6)$ & 0 & 4.09 \\
\hline 2 & $\begin{array}{l}\text { The teaching of grammar } \\
\text { must be done explicitly } \\
\text { rather than implicitly }\end{array}$ & $22(41)$ & $19(36)$ & $6(11)$ & $5(9)$ & $2(3)$ & 4 \\
\hline 3 & $\begin{array}{l}\text { Contrastive analysis of } \\
\text { English with Indonesian } \\
\text { is useful in the study of } \\
\text { the grammar }\end{array}$ & $25(46)$ & $22(41)$ & $4(7)$ & $3(6)$ & 0 & 4.27 \\
\hline 4 & $\begin{array}{l}\text { Contextualized grammar } \\
\text { practice is relevant in the } \\
\text { learning of English } \\
\text { grammar }\end{array}$ & $17(32)$ & $29(53)$ & $5(9)$ & $3(6)$ & 0 & 4.11 \\
\hline 5 & $\begin{array}{l}\text { Studying the rules is } \\
\text { important in learning } \\
\text { English grammar. }\end{array}$ & $11(20)$ & $40(74)$ & $3(6)$ & 0 & 0 & 4.14 \\
\hline 6 & $\begin{array}{l}\text { Listening activities } \\
\text { (news, short stories, etc.) } \\
\text { for discovering } \\
\text { grammatical phenomena } \\
\text { are truly effective. }\end{array}$ & $5(9)$ & $15(28)$ & $8(15)$ & $14(26)$ & $12(22)$ & 2.75 \\
\hline 7 & $\begin{array}{l}\text { Activities of reading } \\
\text { authentic texts for } \\
\text { discovering grammatical } \\
\text { rules are truly effective }\end{array}$ & 0 & $3(6)$ & $3(6)$ & $33(60)$ & $15(28)$ & 1.88 \\
\hline 8 & $\begin{array}{l}\text { Practical exercises are } \\
\text { important in the study of } \\
\text { English grammar }\end{array}$ & $27(50)$ & $22(41)$ & $5(9)$ & 0 & 0 & 4.4 \\
\hline
\end{tabular}




\begin{tabular}{|l|l|c|c|c|c|c|c|}
\hline 9 & $\begin{array}{l}\text { The Study of terminology } \\
\text { is important in the } \\
\text { learning of English } \\
\text { grammar }\end{array}$ & $7(13)$ & $36(67)$ & $5(9)$ & $6(11)$ & 0 & 3.81 \\
\hline 10 & $\begin{array}{l}\text { Syntactic analysis of } \\
\text { phrases and sentences } \\
\text { helps immensely to better } \\
\text { understand English } \\
\text { grammar }\end{array}$ & $9(17)$ & $40(74)$ & $5(9)$ & 0 & 0 & 4.07 \\
\hline
\end{tabular}

The techniques and activities we used to have in grammar classes, I think, are effective. As you know, the classes usually began with the lecturers' presentation about certain language facts. It is then followed by questions and answers about the rules existed in the presentation. What came next was doing exercises in groups or individually. (Interviewee B)

For me, doing exercises related to the grammatical rules I have studied are the most effective techniques and to learn grammar. Lecturers' presentations and explanations are very important. To study grammar alone, without lecturers' guidance, seemed very difficult. (Interviewee C)

Although grammar is very complicated, it can be interesting and challenging to study by using various activities and techniques. Based on my experience, comparing English grammatical rules with the relevant rules in Indonesian, doing contextual exercises are effective. To analyze the structures of given clauses, sentences or phrases is also effective. (Interviewee D)

Lecturers' presentations and guidance are important in learning grammar. Contrastive analysis and contextual exercises are my favorite activities for this. The activities I think boring to study grammar is reading authentic texts for discovering and formulating grammatical rules. It's tiring and time consuming. (Interviewee D)

The respondents' preference with the explicit approach to grammar than the implicit corresponded with the low value given to discovery learning activities (listening to news, short stories, etc. and reading authentic texts). The latter was rated with the lowest figures (2.75 and 1.88) of all the items included in this part of the questionnaire. These figures evidently denote that the students preferred being led by the lecturer rather than finding new things by themselves. 


\section{Conclusion}

As revealed through the findings of this research, a majority of the students English Teaching Study Program of FKIP-UKI basically viewed grammar important and plays an important role in their study of English. They also viewed grammar necessary in writing. However, a majority of them did not perceive that grammar plays an important role in communication and speaking. Consequently, their knowledge in grammar was not automatically applied in language usage. In relation to this, it is highly important to show the correlation of knowledge of grammar and communication skills, including speaking.

Concerning with the techniques and activities for the teaching and learning of grammar, it was revealed that the students English Teaching Study Program of FKIP-UKI preferred explicit than implicit teaching. Practical exercises, contrastive analysis, studying the rules of grammar, and syntactic parsing are four most useful learning activities for the respondents' understanding of the English grammar.

The findings related to the students' view the techniques and activities for the teaching and learning of grammar indicated that the students tended to dislike self-discovery learning technique. Since autonomy is one of the major objectives in any educational program, including grammar teaching, exploring new techniques and activities for more autonomous learning of grammar is very important.

Since this study concentrates on the perceptions of English teacher training students with quite limited respondents from a single institution, future study can probably be carried out by covering a larger number of students from various institutions and regions. Studies can also be carried out to investigate students and lecturers' view in English classes of non-English departments, such as medical faculty, technical faculty, law faculty, and so on. To conduct research for gauging the view of lecturers/teachers on the inclusion of short stories in English classes of secondary schools is also recommended.

\section{References}

Cadierno, T. (1995). Formal instruction from a processing perspective: An investigation into the Spanish past tense. Modern Language Journal, 79, 179-193.

Carroll, S., \& Swain, M. (1993). Explicit and implicit negative feedback: An empirical study of the learning of linguistic generalizations. Studies in Second Language Acquisition, 15, 357-386. 
Corder, S. (1988). Pedagogic grammar. In W. Rutherford \& M. SharwoodSmith (Eds.), Grammar and second language teaching (pp. 123-145). New York: Harper \& Row Publishers, Inc.

Creswell, J., P., Guttman, M., \& Hanson, W. (2003). Advanced mixed methods research designs." In Tashakkori, A. \& Teddlie, C. (Eds.), Handbook on mixed methods in the behavioral and social sciences. Thousand Oaks, Calif: Sage Publications.

Ellis, R. (2002). Methodological options in grammar teaching materials. In Hinkel, E. \& Fotos, S. (Eds.). New perspectives on grammar teaching in second language classrooms (pp. 155-180). New Jersey: Lawrence Erlbaum Associates, Publishers.

Ellis, R. (2006). Current issues in the teaching of grammar: An SLA perspective. TESOL Quarterly, 40(1), 83-106.

Hammond, R. (1988). Accuracy versus communicative competency: The acquisition of grammar in the second language classroom. Hispania, 71, 408-417.

Horowitz, E. (1990). Attending to the affective domain in the foreign language classroom. In S. Magnan (Ed.), Shifting the instructional focus to the learner (pp. 15-33). Middlebury, VY: Northeast Conference on the Teaching of Foreign Languages.

Hudson, Richard. (1998). Is Grammar Teachable? English, 2, 11-14;82-3.

Krashen, S. (1981). Second language acquisition and second language learning. Oxford: Oxford University Press.

Krashen, S. (1985). The input hypothesis: Issues and implications. London: Longman.

Lightbown, P. (1992). What have we here? Some observations on the influence of instruction on L2 learning. In R. Philipson, E. Kellerman, L. Selinker, M. Sharwood Smith, \& M. Swain (Eds.), Foreign language pedagogy research: A commemorative volume for Claus Faerch (pp. 197-212). Clevedon, UK: Multilingual Matters.

Long \& J. Richards (Eds.). (1987). Methodology in TESOL (pp. 33-44). New Jersey: Heinle \& Heinle Publishers.

Nassaji, H \& Fotos, S. (2004). Current developments in research on the teaching of grammar. Annual Review of Applied Linguistics. 24, 126145.

Nassaji, H., \& Swain, M. (2000). A Vygotskian perspective on corrective feedback: The effect of random versus negotiated help on the learning of English articles. Language Awareness, 9, 34-51.

Ozkana, Y. \& Kesen, A. (2009). The third way in grammar instruction. Procedia Social and Behavioral Sciences 1 (2009) 1931-1935. 
Norris, J., \& Ortega, L. (2000). Effectiveness of L2 Instruction: A research synthesis and quantitative meta-analysis. Language Learning, 50, 417428.

Palacios, I.M. (2006, December). The teaching of grammar revisited. Listening to the students' voice. Retrieved on April 21, 2010 from http://www.spertus.es/Publications/ Ignacio/VIAL.pdf

Palmer, F. (1984). Grammar (2nd. Ed). Hardmondsworth: Penguin Books.

Rahimpour, M. \& Salimi, A. (2010). The impact of explicit instruction on foreign language students' performance. Procedia Social and Behavioral Sciences 2 (2010), 1740-1746.

Rutherford, W.E. (1987). Second language grammar: Learning and teaching. New York: Longman.

Swan, M. (1995). Practical english usage. Oxford: Oxford University Press.

Takahashi, M. (2005). Instruction in EFL classes in japan (Doctorial dissertation). The Department of English Linguistics of Kobe Shoin Graduate School of Letters.

Terrell, T. (1977). A natural approach to second language acquisition and learning. The Modern Language Journal, 61, 325-336.

Tomlison, B. (2005). English as a foreign language: Matching procedures to the context of learning. In Hinkel, E. (Ed.), Handbook of research in second language teaching and learning. (pp. 137-153). New Jersey: Lawrence Erlbaum Associates, Publishers.

Ur, P. (1999). Grammar practice activities: A practical guide for teachers (12th ed.). Cambridge: Cambridge University Press.

Wang, S. (2010). The significance of english grammar to middle school students in china. Journal of Language Teaching and Research, 1(3), 313-319.

Zhang, J. (2009). Necessity of grammar teaching. Journal of International Education Studies, 2(2). Retrieved on July 18, 2010 from http://www.ccsenet.org/journal.html 